\title{
Desulfovirgula thermocuniculi gen. nov., sp. nov., a thermophilic sulfate-reducer isolated from a geothermal underground mine in Japan
}

Correspondence

Anna H. Kaksonen

anna.kaksonen@tut.fi

\author{
Anna H. Kaksonen, ${ }^{1}$ Stefan Spring, ${ }^{2}$ Peter Schumann, ${ }^{2}$ \\ Reiner M. Kroppenstedt ${ }^{2}$ and Jaakko A. Puhakka ${ }^{1}$
${ }^{1}$ Institute of Environmental Engineering and Biotechnology, Tampere University of Technology, Tampere, Finland \\ ${ }^{2}$ DSMZ - German Collection of Microorganisms and Cell Cultures, Braunschweig, Germany
}

\begin{abstract}
A thermophilic, Gram-positive, endospore-forming, sulfate-reducing bacterial strain, designated $\mathrm{RL} 8 \mathrm{JIV}^{\top}$, was isolated from a geothermally active underground mine in Japan. Cells were rodshaped and motile. The temperature and $\mathrm{pH}$ ranges for growth were $61-80^{\circ} \mathrm{C}$ (optimum at $69-72^{\circ} \mathrm{C}$ ) and $\mathrm{pH} 6.4-7.9$ (optimum at $\mathrm{pH} 6.8-7.3$ ), and the strain tolerated up to $0.5 \% \mathrm{NaCl}$. Strain RL80JIV ${ }^{\top}$ utilized sulfate, sulfite, thiosulfate and elemental sulfur as electron acceptors. Electron donors utilized were $\mathrm{H}_{2}$ in the presence of $\mathrm{CO}_{2}$, and carboxylic acids. Fermentative growth occurred on lactate and pyruvate. The cell wall contained meso-diaminopimelic acid and the major respiratory isoprenoid quinone was menaquinone MK-7. Major whole-cell fatty acids were iso$\mathrm{C}_{15: 0}$, iso- $\mathrm{C}_{17: 0}$ and $\mathrm{C}_{16: 0}$. Strain RL80JIV ${ }^{\top}$ was found to be affiliated with the thiosulfate-reducer Thermanaeromonas toyohensis DSM $14490^{\top}$ ( $90.9 \% 16 \mathrm{~S}$ rRNA gene sequence similarity) and with the sulfate-reducer Desulfotomaculum thermocisternum DSM $10259^{\top}$ ( $90.0 \%$ similarity). Strain RL80JIV ${ }^{\top}$ is therefore considered to represent a novel species of a new genus, for which the name Desulfovirgula thermocuniculi gen. nov., sp. nov. is proposed. The type strain of Desulfovirgula thermocuniculi is $\mathrm{RL} 80 \mathrm{JIV}^{\top}\left(=\mathrm{DSM} 16036^{\top}=\mathrm{JCM} 13928^{\top}\right)$.
\end{abstract}

Thermophilic sulfate-reducers have increasingly attracted interest owing to their potential in biotechnological applications, such as biodesulfurication of flue gases and biohydrometallurgical processes. The majority of thermophilic sulfate-reducers have been isolated from geothermal habitats, including oilfield waters (Rosnes et al., 1991; Beeder et al., 1994, 1995), hot springs (Zeikus et al., 1983; Nazina et al., 1989; Karnauchow et al., 1992; Henry et al., 1994) and geothermal groundwaters (Daumas et al., 1988; Love et al., 1993). Thermophilic sulfate-reducers include Gram-positive bacteria, such as Desulfotomaculum (Campbell \& Postgate, 1965) and Thermodesulfobium (Mori et al., 2003) within the class 'Clostridia'. Gram-negative sulfate-reducers have been found in genera such as Thermodesulforhabdus (Beeder et al., 1995) and Desulfacinum (Rees et al., 1995) within the class Deltaproteobacteria, Thermodesulfobacterium (Zeikus et al., 1983) and Thermodesulfatator (Moussard et al., 2004) within the class Thermodesulfobacteria and Thermodesulfovibrio (Henry et al., 1994) within the class 'Nitrospira'. Additionally, one archaeal sulfate-reducing genus, Archaeoglobus (Beeder et al., 1994), has been described. Recently, we have reported the enrichment and isolation of

The GenBank/EMBL/DDBJ accession number for the 16S rRNA gene sequence of strain RL80JIV ${ }^{\top}$ is DQ208689. thermophilic sulfate-reducers from a geothermal underground mine in Japan (Kaksonen et al., 2006a, b) and in this paper we describe a novel thermophilic sulfate-reducing bacterium, strain RL80JIV ${ }^{\mathrm{T}}$, isolated from the same mine.

Strain RL80JIV ${ }^{\mathrm{T}}$ was isolated from an underground mine $250 \mathrm{~m}$ below ground, from a black sediment layer beneath a thin red layer on a tunnel wall that was covered with ferric iron. The in situ temperature of the habitat was $70-80{ }^{\circ} \mathrm{C}$. Enrichment and isolation of strain RL80JIV ${ }^{\mathrm{T}}$ were performed at $80{ }^{\circ} \mathrm{C}$ using modified Postgate growth medium ( $\mathrm{pH} 7.0-7.5$ ) (Kaksonen et al., 2006a) with lactate as electron donor. Anaerobic roll-tubes solidified with $1.5 \%$ Gelrite gellan gum were used for isolation. For chemotaxonomic analysis and DNA isolation the strain was cultured at $70{ }^{\circ} \mathrm{C}$ in modified DSM medium 641 containing pyruvate as electron donor. The medium was supplemented with $1 \mathrm{ml}$ selenate/tungstate solution $1^{-1}$ (DSM medium 385), and sodium dithionate $\left(25 \mathrm{mg} \mathrm{l}^{-1}\right)$ was used as the reducing agent instead of $\mathrm{Na}_{2} \mathrm{~S}$.

The isolate was examined via phase-contrast microscopy (Zeiss Axioskop 2). Flagellum staining was performed as described by Heimbrook et al. (1989). Spore formation by the strain was determined microscopically, and by testing for growth after heat treatment $\left(95^{\circ} \mathrm{C}\right.$ for $25 \mathrm{~min}$ ). Gram 
Table 1. Characteristics of strain RL80JIV in comparison with those of its closest phylogenetic relatives

Taxa: 1, strain RL80JIV ${ }^{\mathrm{T}}$; 2, Thermanaeromonas toyohensis (Mori et al., 2002); 3, Desulfotomaculum thermocisternum (Nilsen et al., 1996); 4, Desulfotomaculum kuznetsovii (Nazina et al., 1989); 5, Desulfotomaculum luciae (Liu et al., 1997); 6, Desulfotomaculum thermobenzoicum subsp. thermobenzoicum (Tasaki et al., 1991); 7, Desulfotomaculum thermoacetoxidans (Min \& Zinder, 1990); 8, Desulfotomaculum geothermicum (Daumas et al., 1988); 9, Desulfotomaculum solfataricum (Goorissen et al., 2003); 10, Desulfotomaculum australicum (Love et al., 1993). + , Positive; -, negative; +/-, variable; NR, not reported. All shared the following characteristics: rod-shaped cells, spore formation and oxidation of lactate $(10 \mathrm{mM})$. Strain RL80JIV ${ }^{\mathrm{T}}$ utilized heptanoate, crotonate and glutamate (each $\left.10 \mathrm{mM}\right)$, decanoate $(1 \mathrm{mM})$ and nonanoate $(0.5 \mathrm{mM})$ as electron donors, but did not utilize $\mathrm{Fe}(\mathrm{III})(10 \mathrm{mM})$ as electron acceptor or tartrate, isobutyrate, citrate, mannose, galactose, myo-inositol, lactose or trehalose (each $10 \mathrm{mM})$, pentanol $(5 \mathrm{mM})$, phenylacetate $(3 \mathrm{mM})$, 4-hydroxybenzoate or octanoate (each $2 \mathrm{mM}$ ), dodecanoate or tetradecanoate (each $1 \mathrm{mM}$ ) as electron donors. The concentrations apply only to this study.

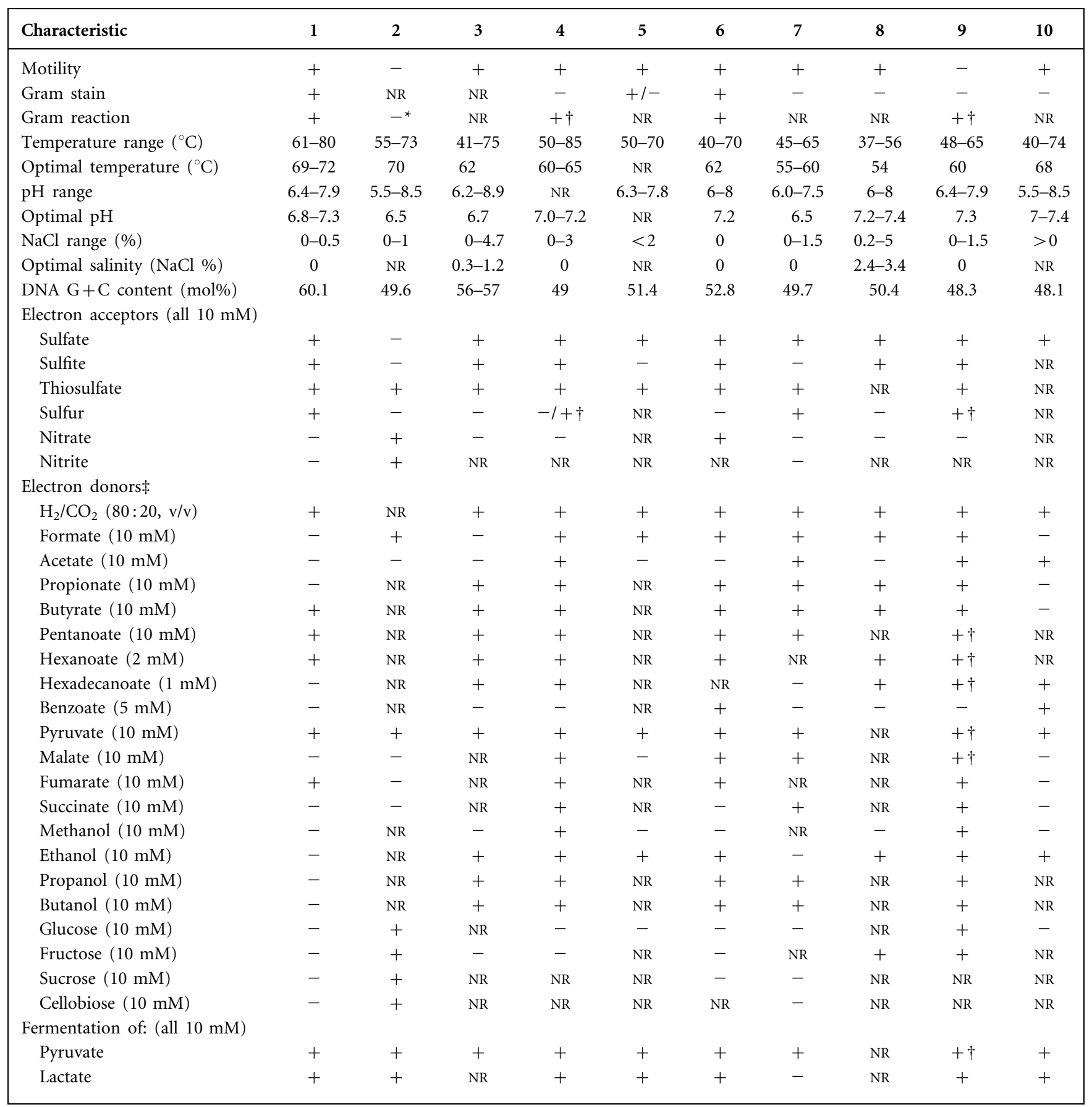

${ }^{\star}$ Gram-positive type cell wall observed by transmission electron microscopy.

$\dagger$ Data obtained from Kaksonen et al. (2006b).

‡With sulfate, except for T. toyohensis, for which thiosulfate was used. 
Table 2. Whole-cell fatty acid composition of strain RL80JIV $^{\top}$

ECL, Equivalent chain length; DMA, dimethyl acetal; $c$, cis isomer.

\begin{tabular}{|c|c|c|}
\hline ECL & Fatty acid & Content (\%) \\
\hline 13.62 & iso- $\mathrm{C}_{14: 0}$ & 0.4 \\
\hline 14.00 & $\mathrm{C}_{14: 0}$ & 1.3 \\
\hline 14.63 & iso- $\mathrm{C}_{15: 0}$ & 36.2 \\
\hline 14.71 & anteiso- $\mathrm{C}_{15: 0}$ & 1.8 \\
\hline 14.95 & $\mathrm{C}_{16: 0}$ aldehyde & 0.5 \\
\hline 15.00 & $\mathrm{C}_{15: 0}$ & 1.2 \\
\hline 15.11 & iso- $\mathrm{C}_{15: 0}$ DMA & 1.3 \\
\hline 15.63 & iso- $\mathrm{C}_{16: 0}$ & 3.9 \\
\hline 16.00 & $\mathrm{C}_{16: 0}$ & 15.7 \\
\hline 16.47 & $\mathrm{C}_{16: 0}$ DMA & 1.9 \\
\hline 16.63 & iso- $\mathrm{C}_{17: 0}$ & 16.6 \\
\hline 16.72 & anteiso- $\mathrm{C}_{17: 0}$ & 1.3 \\
\hline 17.00 & $\mathrm{C}_{17: 0}$ & 0.4 \\
\hline 17.11 & iso- $\mathrm{C}_{17: 0}$ DMA & 7.1 \\
\hline 17.20 & anteiso- $\mathrm{C}_{17: 0}$ DMA & 0.6 \\
\hline 17.72 & $\mathrm{C}_{18: 2} \omega 6,9 c$ & 0.6 \\
\hline 17.77 & $\mathrm{C}_{18: 1} \omega 9 c$ & 2.3 \\
\hline \multirow[t]{2}{*}{18.00} & $\mathrm{C}_{18: 0}$ & 0.7 \\
\hline & Total unidentified & 6.3 \\
\hline
\end{tabular}

type of the cells was determined by both Gram staining and the KOH test (Gregersen, 1978).

The effects of temperature, $\mathrm{pH}$ and $\mathrm{NaCl}$ concentration on growth were determined as previously described (Kaksonen et al., 2006a). The ability of the strain to utilize various electron donors (1-20 mM) was tested in a medium containing $20 \mathrm{mM}$ sulfate. The utilization of various electron acceptors $(10 \mathrm{mM})$ was studied using lactate $(10 \mathrm{mM})$ as the electron donor. Amorphous $\mathrm{Fe}$ (III) oxyhydroxide was formed by neutralizing $\mathrm{FeCl}_{3}$ solution to a $\mathrm{pH}$ of 7 with $\mathrm{NaOH}$. Cultures were incubated for 1-2 weeks. Electron donor utilization was determined by measuring growth (optical density at $660 \mathrm{~nm}$; Shimadzu
UV-1601 spectrophotometer or Ultrospec II LKB Biochrom $4050 \mathrm{UV} /$ visible spectrophotometer), or based on hydrogen sulfide production or substrate conversion as described previously (Kaksonen et al., 2004). Ferrous iron was determined colorimetrically (Shimadzu UV-1601) with ferrozine (Stookey, 1970). Concentrations of sulfate, sulfite, thiosulfate, nitrate and nitrite were determined by using ion chromatography (Dionex DX-120).

Diaminopimelic acid isomers were detected in cell-wall hydrolysates by using TLC as described by Rhuland et al. (1955) and Kaksonen et al. (2006b). Respiratory isoprenoid quinones were extracted and analysed according to the methods described by Collins \& Jones (1981), Monciardini et al. (2003) and Groth et al. (1996) by using HPLC and GCMS (Kaksonen et al., 2006b).

Fatty acid methyl esters of cellular fatty acids were obtained by saponification, methylation, extraction and base wash, as described by Kämpfer \& Kroppenstedt (1996), Kroppenstedt (1985) and Miller (1982). The fatty acid methyl mixtures were separated on a gas chromatograph (Hewlett Packard 5890 Series II) as described previously (Kaksonen et al., 2006b) and analysed by using the Microbial Identification Standard software package Sherlock version 4.5 (Sasser, 1990).

Methods for the amplification, sequencing and phylogenetic analysis of the 16S rRNA gene were performed as described previously (Kaksonen et al., 2006a). Genomic DNA for $\mathrm{G}+\mathrm{C}$ content determination was released by rupturing cells using a French pressure cell (Thermo Spectronic) and was purified by chromatography on hydroxyapatite (Cashion et al., 1977). The DNA was hydrolysed with P1 nuclease and the nucleotides were dephosphorylated with bovine alkaline phosphatase (Mesbah et al., 1989). The $\mathrm{G}+\mathrm{C}$ content of the resulting deoxyribonucleosides was determined by using reversed-phase HPLC (Shimadzu Corp.) and calculated from the ratio of deoxyguanosine (dG) and thymidine (dT) (Tamaoka \& Komagata, 1984; Mesbah et al., 1989).

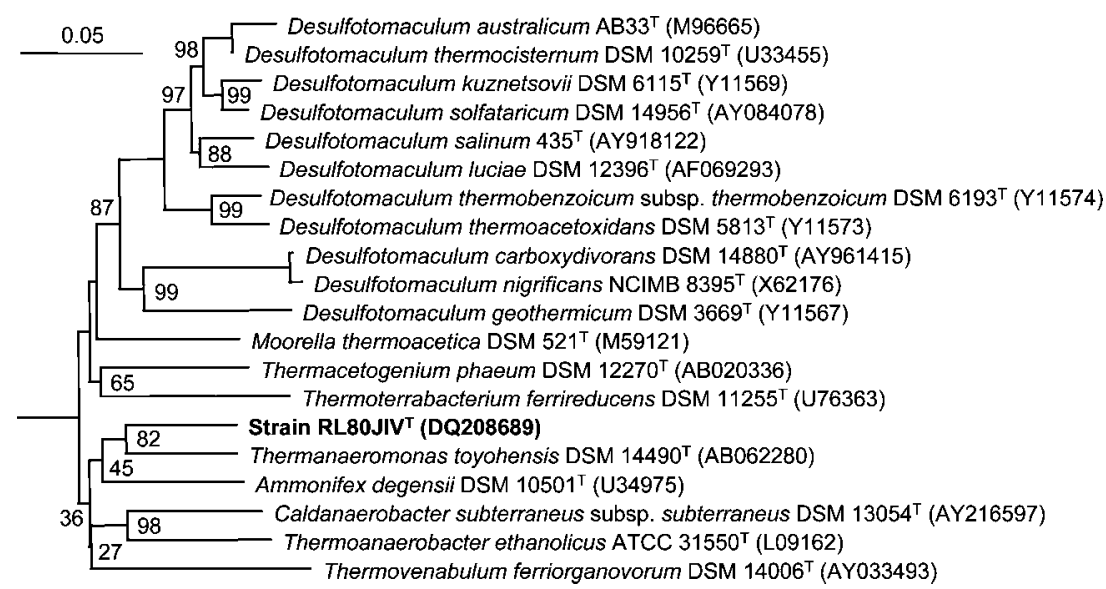

Fig. 1. Phylogenetic tree generated using distance-matrix and neighbour-joining methods based on the 16S rRNA gene sequences of strain RL80JIV ${ }^{\top}$ (1436 bp between Escherichia coli positions 28 and 1453) and related taxa. Archaeoglobus veneficus SNP6 ${ }^{\top}$ (Y10011) was used as an outgroup (not shown). Numbers at nodes represent bootstrap percentages based on 1000 samplings. Bar, 0.05 nucleotide changes per position. 
Cells of strain RL80JIV ${ }^{\mathrm{T}}$ were straight or slightly curved rods, $0.8-1 \mu \mathrm{m}$ in diameter and $2-6 \mu \mathrm{m}$ in length. The strain formed spherical spores which germinated after a heat shock treatment at $95^{\circ} \mathrm{C}$ for $25 \mathrm{~min}$. The spores were located centrally or subterminally and sporulation caused swelling of the cells, creating a lemon-shaped appearance. Cells were motile with two or more flagella and Grampositive as determined by both Gram staining and the $\mathrm{KOH}$ test. Data for temperature, $\mathrm{pH}$ and $\mathrm{NaCl}$ range for growth of strain RL80JIV ${ }^{\mathrm{T}}$ are given in Table 1. The temperature at the sampling point in the mine was $70-80{ }^{\circ} \mathrm{C}$, which is also within the growth range of strain RL80JIV ${ }^{\mathrm{T}}$. Strain RL80JIV $^{\mathrm{T}}$ was able to use sulfate, sulfite, thiosulfate and elemental sulfur as electron acceptors. RL80JIV ${ }^{\mathrm{T}}$ utilized $\mathrm{H}_{2}$ in the presence of $\mathrm{CO}_{2}$ and various carboxylic acids or their sodium salts as electron donors (Table 1). A number of electron donors (e.g. lactate, pyruvate, crotonate, pentanoate and hexanoate) were oxidized to acetate, whereas no acetate accumulated during the oxidation of others (e.g. fumarate and glutamate). The strain fermented lactate and pyruvate.

The cell wall of strain RL80JIV ${ }^{\mathrm{T}}$ contained meso-diaminopimelic acid and the major respiratory isoprenoid quinone was menaquinone MK-7. The whole-cell fatty acid composition of strain RL80JIV ${ }^{\mathrm{T}}$ is given in Table 2. Significant proportions of saturated fatty acids were found; the major fatty acids were iso- $\mathrm{C}_{15: 0}$, iso- $\mathrm{C}_{17: 0}$ and $\mathrm{C}_{16: 0}$ (Table 2).

Phylogenetic analysis (Fig. 1) revealed that strain RL80JIV ${ }^{\mathrm{T}}$ clustered with the thiosulfate-reducing bacterium Thermanaeromonas toyohensis DSM $14490^{\mathrm{T}}$ (90.9\% $16 \mathrm{~S}$ rRNA gene sequence similarity), an isolate from a similar geothermal mine environment (Mori et al., 2002), and with the sulfate-reducer Desulfotomaculum thermocisternum DSM $10259^{\mathrm{T}}(90.0 \%$ sequence similarity). The $\mathrm{G}+\mathrm{C}$ content of the total DNA of strain RL80JIV ${ }^{\mathrm{T}}(60.1 \mathrm{~mol} \%)$ (Table 1) was higher than that of T. toyohensis ( $49.6 \mathrm{~mol} \%$ ) and those reported for thermophilic Desulfotomaculum species (47-57 mol\%) (Castro et al., 2000; Goorissen et al., 2003; Liu et al., 1997), thereby differentiating strain RL80JIV $^{\mathrm{T}}$ from T. toyohensis and species of the genus Desulfotomaculum.

Strain RL80JIV ${ }^{\mathrm{T}}$ exhibits many features typical for the sulfate-reducing members of the genus Desulfotomaculum and the thiosulfate-reducing members of the genus Thermanaeromonas, such as rod-shaped, Gram-positive, spore-forming cells and MK-7 as the major menaquinone. However, based on 16S rRNA gene sequence analysis, the strain is only distantly related to representatives of the two genera. Moreover, the DNA G+C content of strain RL80JIV $^{\mathrm{T}}$ is comparatively high and its closest phylogenetic relative, $T$. toyohensis, does not reduce sulfate. The phylogenetic and phenotypic distinctiveness of strain RL80JIV $^{\mathrm{T}}$ indicates that it represents a novel species of a new genus, for which the name Desulfovirgula thermocuniculi gen. nov., sp. nov. is proposed.

\section{Description of Desulfovirgula gen. nov.}

Desulfovirgula (De.sul.fo.vir'gu.la. L. pref. de from; L. n. sulfur sulfur; L. fem. n. virgula twig or rod, N.L. fem. n. Desulfovirgula a rod that reduces sulfur compounds).

Cells are rod-shaped, spore-forming, Gram-positive and thermophilic. Sulfate and other sulfur compounds are used as electron acceptors. Optimal growth occurs at neutral $\mathrm{pH}$. The cell wall contains meso-diaminopimelic acid and MK-7 is the major menaquinone. Major cellular fatty acids are iso-

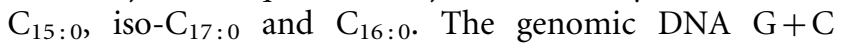
content of the type species is $60.1 \mathrm{~mol} \%$ (as determined by HPLC). Phylogenetic position based on 16S rRNA gene sequence analysis is within the Gram-positive bacteria. The type species is Desulfovirgula thermocuniculi.

\section{Description of Desulfovirgula thermocuniculi sp. nov.}

Desulfovirgula thermocuniculi (ther.mo.cu.ni'cu.li. Gr. adj. thermos hot; L. n. cuniculus mine; N.L. gen. n. thermocuniculi of a hot mine).

Has the following properties in addition to those given in the description of the genus. Cells $(0.8-1 \times 2-6 \mu \mathrm{m})$ are motile. Growth occurs at $61-80^{\circ} \mathrm{C}$ (optimum $69-72{ }^{\circ} \mathrm{C}$ ), pH 6.4-7.9 (optimum $\mathrm{pH}$ 6.8-7.3) and $\mathrm{NaCl}$ concentrations of $0-0.5 \%$ (optimum $0 \% \mathrm{NaCl}$ ). Sulfate, sulfite, thiosulfate and elemental sulfur are used as electron acceptors, but $\mathrm{Fe}(\mathrm{III})$, nitrate and nitrite are not. $\mathrm{H}_{2}$ in the presence of $\mathrm{CO}_{2}$ and various carboxylic acids or their sodium salts (Table 1) are used as electron donors. Fermentative growth occurs on lactate and pyruvate.

The type strain, RL80JIV ${ }^{\mathrm{T}}\left(=\mathrm{DSM} 16036^{\mathrm{T}}=\mathrm{JCM} 13928^{\mathrm{T}}\right.$ ), was isolated from a geothermally active underground mine in Japan.

\section{Acknowledgements}

This work was supported by the Finnish Funding Agency for Technology and Innovation, Outokumpu Oyj, Finland, Finnish Graduate School in Environmental Science and Technology, Academy of Finland and European Commission (BioMinE contract 500329 and a grant for the DSMZ large-scale facility). Annukka Hämäläinen, Esther Schüler, Anika Vester and Marlen Jando are thanked for their technical assistance.

\section{References}

Beeder, J., Nilsen, R. K., Rosnes, J. T., Torsvik, T. \& Lien, T. (1994). Archaeoglobus fulgidus isolated from hot North Sea oil field waters. Appl Environ Microbiol 60, 1227-1231.

Beeder, J., Torsvik, T. \& Lien, T. (1995). Thermodesulforhabdus norvegicus gen. nov., sp. nov., a novel thermophilic sulfate-reducing bacterium from oil field water. Arch Microbiol 164, 331-336.

Campbell, L. L. \& Postgate, J. R. (1965). Classification of the sporeforming sulfate-reducing bacteria. Bacteriol Rev 29, 359-363. 
Cashion, P., Holder-Franklin, M. A., McCully, J. \& Franklin, M. (1977). A rapid method for the base ratio determination of bacterial DNA. Anal Biochem 81, 461-466.

Castro, H. F., Williams, N. H. \& Ogram, A. (2000). Phylogeny of sulfate-reducing bacteria. FEMS Microbiol Ecol 31, 1-9.

Collins, M. D. \& Jones, D. (1981). Distribution of isoprenoid quinone structural types in bacteria and their taxonomic implications. Microbiol Rev 45, 316-354.

Daumas, S., Cord-Ruwisch, R. \& Garcia, J. L. (1988). Desulfotomaculum geothermicum sp. nov., a thermophilic, fatty aciddegrading, sulfate-reducing bacterium isolated with $\mathrm{H}_{2}$ from geothermal ground water. Antonie van Leeuwenhoek 54, 165-178.

Goorissen, H. P., Boschker, H. T. S., Stams, A. J. M. \& Hansen, T. A. (2003). Isolation of thermophilic Desulfotomaculum strains with methanol and sulfite from solfataric mud pools, and characterization of Desulfotomaculum solfataricum sp. nov. Int J Syst Evol Microbiol 53, 1223-1229.

Gregersen, T. (1978). Rapid method for distinction of Gramnegative from Gram-positive bacteria. Eur J Appl Microbiol Biotechnol 5, 123-127.

Groth, I., Schumann, P., Weiss, N., Martin, K. \& Rainey, F. A. (1996). Agrococcus jenesis gen. nov., sp. nov., a new genus of actinomycetes with diaminobutyric acid in the cell wall. Int J Syst Bacteriol 46, 234-239.

Heimbrook, M. E., Wang, W. L. L. \& Campbell, G. (1989). Staining bacterial flagella easily. J Clin Microbiol 27, 2612-2615.

Henry, E. A., Devereux, R., Maki, J. S., Gilmour, C. C., Woese, C. R., Mandelco, L., Schauder, R., Remsen, C. C. \& Mitchell, R. (1994). Characterization of a new thermophilic sulfate-reducing bacterium Thermodesulfovibrio yellowstonii, gen. nov. and sp. nov.: its phylogenetic relationship to Thermodesulfobacterium commune and their origins deep within the bacterial domain. Arch Microbiol 161, 62-69.

Kaksonen, A. H., Plumb, J. J., Robertson, W. J., Franzmann, P. D., Gibson, J. A. E. \& Puhakka, J. A. (2004). Culturable diversity and community fatty acid profiling of sulfate-reducing fluidized-bed reactors treating acidic, metal-containing wastewater. Geomicrobiol J 21, 469-480.

Kaksonen, A. H., Plumb, J. J., Robertson, W. J., Spring, S., Schumann, P., Franzmann, P. D. \& Puhakka, J. A. (2006a). Novel thermophilic sulfate-reducing bacteria from a geothermally active underground mine in Japan. Appl Environ Microbiol 72, 3759-3762.

Kaksonen, A. H., Spring, S., Schumann, P., Kroppenstedt, R. M. \& Puhakka, J. A. (2006b). Desulfotomaculum thermosubterraneum sp. nov., a thermophilic sulfate-reducer isolated from an underground mine located in a geothermally active area. Int J Syst Evol Microbiol 56, 2603-2608.

Kämpfer, P. \& Kroppenstedt, R. M. (1996). Numerical analysis of fatty acid patterns of coryneform bacteria and related taxa. Can J Microbiol 42, 989-1005.

Karnauchow, T. M., Koval, S. F. \& Jarrell, K. F. (1992). Isolation and characterization of 3 thermophilic anaerobes from a St. Lucia hot spring. Syst Appl Microbiol 15, 296-310.

Kroppenstedt, R. M. (1985). Fatty acid and menaquinone analysis of actinomycetes and related organisms. In Chemical Methods in Bacterial Systematics, pp. 173-179. Edited by M. Goodfellow \& D. E. Minnikin. London: Academic Press.

Liu, Y., Karnauchow, T. M., Jarrell, K. F., Balkwill, D. L., Drake, G. R., Ringelberg, D., Clarno, R. \& Boone, D. R. (1997). Description of two new thermophilic Desulfotomaculum spp., Desulfotomaculum putei sp. nov., from a deep terrestrial subsurface, and Desulfotomaculum luciae sp. nov., from a hot spring. Int J Syst Bacteriol 47, 615-621.
Love, C. A., Patel, B. K. C., Nichols, P. D. \& Stackebrandt, E. (1993). Desulfotomaculum australicum, sp. nov., a thermophilic sulfatereducing bacterium isolated from the Great Artesian Basin of Australia. Syst Appl Microbiol 16, 244-251.

Mesbah, M., Premachandran, U. \& Whitman, W. B. (1989). Precise measurement of the $\mathrm{G}+\mathrm{C}$ content of deoxyribonucleic acid by highperformance liquid chromatography. Int J Syst Bacteriol 39, 159-167.

Miller, L. T. (1982). Single derivatization method for routine analysis of bacterial whole-cell fatty acid methyl esters, including hydroxy acids. J Clin Microbiol 16, 584-586.

Min, H. \& Zinder, S. H. (1990). Isolation and characterization of a thermophilic sulfate-reducing bacterium Desulfotomaculum thermoacetoxidans sp. nov. Arch Microbiol 153, 399-404.

Monciardini, P., Cavaletti, L., Schumann, P., Rohde, M. \& Donadio, S. (2003). Conexibacter woesei gen. nov., sp. nov., a novel representative of a deep evolutionary line of descent within the class Actinobacteria. Int J Syst Evol Microbiol 53, 569-576.

Mori, K., Hanada, S., Maruyama, A. \& Marumo, K. (2002). Thermanaeromonas toyohensis gen. nov., sp. nov., a novel thermophilic anaerobe isolated from a subterranean vein in the Toyoha Mines. Int J Syst Evol Microbiol 52, 1675-1680.

Mori, K., Kim, H., Kakegawa, T. \& Hanada, S. (2003). A novel lineage of sulfate-reducing microorganisms: Thermodesulfobiaceae fam. nov., Thermodesulfobium narugense, gen. nov., sp. nov., a new thermophilic isolate from a hot spring. Extremophiles 7, 283-290.

Moussard, H., L'Haridon, S., Tindall, B. J., Banta, A., Schumann, P., Stackebrandt, E., Reysenbach, A.-L. \& Jeanthon, C. (2004). Thermodesulfatator indicus gen. nov., sp. nov., a novel thermophilic chemolithoautotrophic sulfate-reducing bacterium isolated from the Central Indian Ridge. Int J Syst Evol Microbiol 54, 227-233.

Nazina, T. N., Ivanova, A. E., Kanchaveli, L. P. \& Rozanova, E. P. (1989). A new sporeforming thermophilic methylotrophic sulfatereducing bacterium, Desulfotomaculum kuznetsovii sp. nov. Microbiology (English translation of Mikrobiologiia) 57, 659-663.

Nilsen, R. K., Torsvik, T. \& Lien, T. (1996). Desulfotomaculum thermocisternum sp. nov., a sulfate-reducer isolated from a hot North Sea oil reservoir. Int J Syst Bacteriol 46, 397-402.

Rees, G. N., Grassia, G. S., Sheehy, A. J., Dwivedi, P. P. \& Patel, B. K. C. (1995). Desulfacinum infernum gen. nov., sp. nov., a thermophilic sulfate-reducing bacterium from a petroleum reservoir. Int J Syst Bacteriol 45, 85-89.

Rhuland, L. E., Work, E., Denman, R. F. \& Hoare, D. S. (1955). The behaviour of the isomers of $\alpha, \varepsilon$-diaminopimelic acid on paper chromatograms. J Am Chem Soc 77, 4844-4846.

Rosnes, J. T., Torsvik, T. \& Lien, T. (1991). Spore-forming thermophilic sulfate-reducing bacteria isolated from North Sea oil field waters. Appl Environ Microbiol 57, 2302-2307.

Sasser, M. (1990). Identification of bacteria by gas chromatography of cellular fatty acids. USFCC Newsl 20, 1-6.

Stookey, L. L. (1970). Ferrozine - a new spectrophotometric reagent for iron. Anal Chem 42, 779-781.

Tamaoka, J. \& Komagata, K. (1984). Determination of DNA base composition by reversed-phase high-performance liquid chromatography. FEMS Microbiol Lett 25, 125-128.

Tasaki, M., Kamagata, Y., Nakamura, K. \& Mikami, E. (1991). Isolation and characterization of a thermophilic benzoate-degrading, sulfate-reducing bacterium, Desulfotomaculum thermobenzoicum sp. nov. Arch Microbiol 155, 348-352.

Zeikus, J. G., Dawson, M. A., Thompson, T. E., Ingvorsen, K. \& Hatchikian, E. C. (1983). Microbial ecology of volcanic sulfidogenesis: isolation and characterization of Thermodesulfobacterium commune gen. nov. and sp. nov. J Gen Microbiol 129, 1159-1169. 